\title{
Quantifying nitrogen losses in oil palm plantations: models and challenges
}

\section{Supplementary material}

Table SM1. Nominal, minimum and maximum values of inputs variables and parameters, used for the Morris' sensitivity analysis. EF: emission factor; C: carbon; N: nitrogen; BNF: biological nitrogen fixation; EFB: empty fruit bunches, i.e. organic fertiliser.

\begin{tabular}{|c|c|c|c|}
\hline Input variables and parameters & $\begin{array}{c}\text { Nominal } \\
\text { (min.-max.)* }\end{array}$ & Unit & References* \\
\hline Rainfall & $\begin{array}{c}2407 \\
(1500-3000)\end{array}$ & mm.yr-1 & Ecozones, from FAO (2001) \\
\hline Mean temperature & $\begin{array}{c}28 \\
(20-30)\end{array}$ & ${ }^{\circ} \mathrm{C}$ & Ecozones, from FAO (2001) \\
\hline Soil bulk density & $\begin{array}{c}1430 \\
(860-1550)\end{array}$ & $\mathrm{kg} \cdot \mathrm{m}^{-3}$ & $\begin{array}{l}\text { (Soil taxanomy, from USDA, 1999) } \\
\text { (Khasanah et al., 2015) }\end{array}$ \\
\hline Soil carbon content & $\begin{array}{c}1.68 \\
(0.6-2.38)\end{array}$ & $\%$ & $\begin{array}{l}\text { (Corley and Tinker, 2003, p.84) (Khasanah et } \\
\text { al., 2015) (Soil taxanomy, from USDA, 1999) }\end{array}$ \\
\hline Soil clay content & $\begin{array}{c}31 \\
(1.6-35)\end{array}$ & $\%$ & (Soil taxonomy, from USDA, 1999) \\
\hline Soil C/N & $\begin{array}{c}11 \\
(10-12)\end{array}$ & - & (Nemecek, 2012) \\
\hline Soil N organic / N total & $\begin{array}{c}0.85 \\
(0.68-1)\end{array}$ & - & $\pm 20 \%$ (Nemecek, 2012) \\
\hline Soil N mineralisation rate & $\begin{array}{c}1.6 \\
(1.28-1.92)\end{array}$ & $\%$ & $\pm 20 \%$ (Roy, 2005) \\
\hline Soil N organic & $\begin{array}{c}5500 \\
(1700-5700)\end{array}$ & kgN.ha $^{-1}$ & $\begin{array}{l}\text { (Nemecek, 2012) (Soil taxanomy, from } \\
\text { USDA, 1999) }\end{array}$ \\
\hline Soil pH & $\begin{array}{c}4.5 \\
(4-6)\end{array}$ & - & (Corley and Tinker, 2003, p.84) \\
\hline Oil palm rooting depth & $\begin{array}{c}1 \\
(0.5-5)\end{array}$ & $\mathrm{m}$ & $\begin{array}{l}\text { (Jourdan and Rey, 1997);(Schroth et al., } \\
\text { 2000); (Sommer et al., 2000); (Ng et al., } \\
\text { 2003); (Corley and Tinker, 2003); (Nelson et } \\
\text { al., 2006); (Lehmann, 2003); } \\
\text { (Paramananthan, 2015) }\end{array}$ \\
\hline Oil palm $\mathrm{N}$ uptake & $\begin{array}{c}189 \\
(40-380)\end{array}$ & kgN.ha ${ }^{-1} \cdot \mathrm{yr}^{-1}$ & $\begin{array}{l}\text { (Xaviar, 2000);(Goh et al., 2003);(Tan, 1976); } \\
\text { (Tan, 1977);(Ng, 1977);(Pushparajah and } \\
\text { Chew, 1998); (Henson, 1999); (Ng et al., } \\
\text { 1999); (Ng and Thamboo, 1967); (Ng et al., } \\
\text { 1968); (Foster and Parabowo, 2003) }\end{array}$ \\
\hline $\begin{array}{l}\mathrm{N} \text { released by felled palms (above- and } \\
\text { below-ground) }\end{array}$ & $\begin{array}{c}275 \\
(0-321)\end{array}$ & $\begin{array}{l}\mathrm{kgN} \mathrm{ha}^{-1} \cdot \mathrm{yr}^{-1} \\
\text { ( } \mathrm{N} \text { is released } \\
\text { in two years) }\end{array}$ & $\begin{array}{l}\text { (Khalid et al., 1999b);(Khalid et al., 1999a); } \\
\text { (Redshaw, 2003); (Schmidt, 2007) }\end{array}$ \\
\hline $\begin{array}{l}\mathrm{N} \text { released by palm residues (fronds, } \\
\text { roots, etc.) }\end{array}$ & $\begin{array}{c}108 \\
(0-182)\end{array}$ & kgN.ha ${ }^{-1} \cdot \mathrm{yr}^{-1}$ & $\begin{array}{l}\text { (Corley and Tinker, 2003); (Redshaw, 2003); } \\
\text { (Carcasses, 2004); (Turner and Gillbanks, } \\
\text { 2003); (Schmidt, 2007); (Dufrêne, 1989); } \\
\text { (Lamade et al., 1996); (Henson and Chai, } \\
\text { 1997); (Jourdan et al., 2003) }\end{array}$ \\
\hline Mineral fertiliser amount & $\begin{array}{c}94 \\
(25-206)\end{array}$ & kgN.ha ${ }^{-1} \cdot \mathrm{yr}^{-1}$ & $\begin{array}{l}\text { (Henson, 2004); (Banabas, 2007); (Choo et } \\
\text { al., 2011); (Foster, 2003); (FAO, 2004, In } \\
\text { Schmidt, 2007); (Carcasses, 2004); (Hansen, } \\
\text { 2005); (United Plantations Berhad, 2006); } \\
\text { (Wicke et al., 2008) }\end{array}$ \\
\hline
\end{tabular}




\begin{tabular}{|c|c|c|c|}
\hline Urea rate in mineral fertiliser & $\begin{array}{c}25 \\
(0-100) \\
\end{array}$ & $\%$ & $\begin{array}{l}\text { (FAO, 2004, In Schmidt, 2007); (Carcasses, } \\
\text { 2004) }\end{array}$ \\
\hline Organic fertiliser amount (EFB) & $\begin{array}{c}184 \\
(0-228)\end{array}$ & kgN.ha ${ }^{-1} \cdot \mathrm{yr}^{-1}$ & (Banabas, 2007); (Redshaw, 2003) \\
\hline Atmospheric $\mathrm{N}$ deposition & $\begin{array}{c}18 \\
(8-20) \\
\end{array}$ & $\mathrm{kgN} \cdot \mathrm{ha}^{-1} \cdot \mathrm{yr}^{-1}$ & $\begin{array}{l}\text { (Agamuthu and Broughton, 1985); (Chew et } \\
\text { al., 1999); (Trebs et al., 2006) }\end{array}$ \\
\hline Biological N fixation & $\begin{array}{c}150 \\
(0-190)\end{array}$ & kgN.ha' ${ }^{-1} \cdot \mathrm{yr}^{-1}$ & $\begin{array}{l}\text { (Giller and Fairhurst, 2003); (Ruiz and } \\
\text { López, 2014); (Broughton et al., 1977); } \\
\text { (Agamuthu and Broughton, 1985); }\end{array}$ \\
\hline Legume N uptake & $\begin{array}{c}66 \\
(0-150) \\
\end{array}$ & kgN.ha ${ }^{-1} \cdot \mathrm{yr}^{-1}$ & (Agamuthu and Broughton, 1985) \\
\hline $\mathrm{N}$ released by legume residues & $\begin{array}{c}120 \\
(0-190)\end{array}$ & kgN.ha' ${ }^{-1} \cdot \mathrm{yr}^{-1}$ & $\begin{array}{l}\text { (Agamuthu and Broughton, 1985); } \\
\text { (Pushparajah, 1981) }\end{array}$ \\
\hline $\begin{array}{l}\text { EF (IPCC 2006) Leaching and runoff, } \\
\text { from mineral and organic fertilisers and } \\
\text { BNF }\end{array}$ & $\begin{array}{c}30 \\
(10-80)\end{array}$ & $\%$ & (IPCC, 2006) \\
\hline $\begin{array}{l}\text { EF (IPCC 2006) } \mathrm{NH}_{3} \text { from mineral } \\
\text { fertiliser }\end{array}$ & $\begin{array}{c}10 \\
(3-30)\end{array}$ & $\%$ & (IPCC, 2006) \\
\hline $\begin{array}{l}\text { EF (IPCC 2006) } \mathrm{NH}_{3} \text { from organic } \\
\text { fertiliser }\end{array}$ & $\begin{array}{c}20 \\
(5-50)\end{array}$ & $\%$ & (IPCC, 2006) \\
\hline $\begin{array}{l}\mathrm{EF} \text { (IPCC 2006) } \mathrm{N}_{2} \mathrm{O} \text { from mineral and } \\
\text { organic fertilisers, BNF and plant } \\
\text { residues }\end{array}$ & $\begin{array}{c}1 \\
(0.3-3)\end{array}$ & $\%$ & (IPCC, 2006) \\
\hline $\begin{array}{l}\text { EF (Mosier 1998) Leaching and runoff } \\
\text { from mineral and organic fertilisers }\end{array}$ & $\begin{array}{c}30 \\
(3-57)\end{array}$ & $\%$ & $\pm 90 \%$ \\
\hline $\begin{array}{l}\text { EF (Mosier 1998) } \mathrm{NH}_{3} \text { from mineral } \\
\text { fertiliser }\end{array}$ & $\begin{array}{c}10 \\
(1-19) \\
\end{array}$ & $\%$ & $\pm 90 \%$ \\
\hline $\begin{array}{l}\text { EF (Mosier 1998) } \mathrm{NH}_{3} \text { from organic } \\
\text { fertiliser }\end{array}$ & $\begin{array}{c}20 \\
(2-38)\end{array}$ & $\%$ & $\pm 90 \%$ \\
\hline $\begin{array}{l}\mathrm{EF} \text { (Mosier 1998) } \mathrm{N}_{2} \mathrm{O} \text { from mineral } \\
\text { and organic fertilisers, BNF and plant } \\
\text { residues }\end{array}$ & $\begin{array}{c}1.25 \\
(0.125-2.375)\end{array}$ & $\%$ & $\pm 90 \%$ \\
\hline $\begin{array}{l}\text { EF (Asman 1992) } \mathrm{NH}_{3} \text { from } \\
\text { Ammonium Sulfate }\end{array}$ & $\begin{array}{c}8 \\
(0.8-15.2) \\
\end{array}$ & $\%$ & $\pm 90 \%$ \\
\hline EF (Asman 1992) $\mathrm{NH}_{3}$ from Urea & $\begin{array}{c}15 \\
(1.5-28.5)\end{array}$ & $\%$ & $\pm 90 \%$ \\
\hline $\begin{array}{l}\text { EF (Schmidt 2007) } \mathrm{NH}_{3} \text { volatilisation } \\
\text { from Ammonium Sulfate }\end{array}$ & $\begin{array}{c}2 \\
(0.2-3.8)\end{array}$ & $\%$ & $\pm 90 \%$ \\
\hline $\begin{array}{l}\text { EF (Schmidt 2007) } \mathrm{NH}_{3} \text { volatilisation } \\
\text { from Urea }\end{array}$ & $\begin{array}{c}30 \\
(27-48)\end{array}$ & $\%$ & $\begin{array}{l}\text { (Corley and Tinker, 2003, In Schmidt, } 2007 \\
\text { p102) }\end{array}$ \\
\hline EF (Agrammon 2009) $\mathrm{NH}_{3}$ from leaves & $\begin{array}{c}2 \\
(0.2-3.8)\end{array}$ & kgN.ha ${ }^{-1} \cdot \mathrm{yr}^{-1}$ & $\pm 90 \%$ \\
\hline $\begin{array}{l}\text { EF (Agrammon 2009) } \mathrm{NH}_{3} \text { from } \\
\text { organic fertiliser }\end{array}$ & $\begin{array}{c}35 \\
(30-80)\end{array}$ & $\%$ & $\begin{array}{l}\text { (Agrammon Group, 2009, In (Nemecek et al., } \\
\text { 2014) }\end{array}$ \\
\hline $\begin{array}{l}\text { EF (Nemecek 2007) } \mathrm{NO}_{\mathrm{x}} \text { emissions } \\
\text { from } \mathrm{N}_{2} \mathrm{O} \text { emissions }\end{array}$ & $\begin{array}{c}21 \\
(2.1-39.9) \\
\end{array}$ & $\%$ & $\pm 90 \%$ \\
\hline $\begin{array}{l}\text { EF (Crutzen 2008) } \mathrm{N}_{2} \mathrm{O} \text { from mineral } \\
\text { fertiliser and BNF }\end{array}$ & $\begin{array}{c}4 \\
(3-5) \\
\end{array}$ & $\%$ & (Crutzen et al., 2008) \\
\hline $\begin{array}{l}\text { EF (EMEP 2013) } \mathrm{NO}_{\mathrm{x}} \text { from mineral } \\
\text { fertiliser }\end{array}$ & $\begin{array}{c}2.6 \\
(0.5-10.4) \\
\end{array}$ & $\%$ & $\begin{array}{l}\text { (Stehfest and Bouwman, 2006, In European } \\
\text { Environment Agency, 2013) }\end{array}$ \\
\hline $\begin{array}{l}\text { EF (EMEP 2013) } \mathrm{NH}_{3} \text { from } \\
\text { Ammonium Sulfate, low } \mathrm{pH}\end{array}$ & $\begin{array}{c}1.3 \\
(0.13-2.47)\end{array}$ & $\%$ & $\pm 90 \%$ \\
\hline $\begin{array}{l}\text { EF (EMEP 2013) } \mathrm{NH}_{3} \text { from } \\
\text { Ammonium Sulfate, high } \mathrm{pH}\end{array}$ & $\begin{array}{c}27 \\
(2.7-51.3)\end{array}$ & $\%$ & $\pm 90 \%$ \\
\hline $\begin{array}{l}\text { EF (EMEP 2013) } \mathrm{NH}_{3} \text { from Urea, low } \\
\mathrm{pH}\end{array}$ & $\begin{array}{c}24.3 \\
(2.43-46.17)\end{array}$ & $\%$ & $\pm 90 \%$ \\
\hline EF (EMEP 2013) $\mathrm{NH}_{3}$ from Urea, high & 24.3 & $\%$ & $\pm 90 \%$ \\
\hline
\end{tabular}




\begin{tabular}{|c|c|c|c|}
\hline $\mathrm{pH}$ & $(2.43-46.17)$ & & \\
\hline $\begin{array}{l}\text { EF (Vinther and Hansen 2004) } \mathrm{N}_{2} \mathrm{O} \\
\text { from mineral and organic fertilisers, } \\
\text { BNF and plant residues }\end{array}$ & $\begin{array}{c}1 \\
(0.1-1.9)\end{array}$ & $\%$ & $\pm 90 \%$ \\
\hline $\begin{array}{l}\text { Parameter (Vinther and Hansen 2004) } \\
\mathrm{N}_{2} / \mathrm{N}_{2} \mathrm{O} \text { rate }\end{array}$ & $\begin{array}{c}3 \\
(0.3-5.7)\end{array}$ & $\%$ & $\pm 90 \%$ \\
\hline Parameter (Meier 2014) N Use Rate & $\begin{array}{c}70 \\
(7-133)\end{array}$ & - & $\pm 90 \%$ \\
\hline Parameter 1 (Shcherbak et al., 2014) & $\begin{array}{c}0.0181 \\
(0.017-0.019)\end{array}$ & - & (Shcherbak et al., 2014) \\
\hline Parameter 2 (Shcherbak et al., 2014) & $\begin{array}{c}6.58 \\
(6.45-6.71)\end{array}$ & - & (Shcherbak et al., 2014) \\
\hline
\end{tabular}

*When no references are mentioned, the range was set arbitrary to $\pm 90 \%$, otherwise the range is taken from the references. 


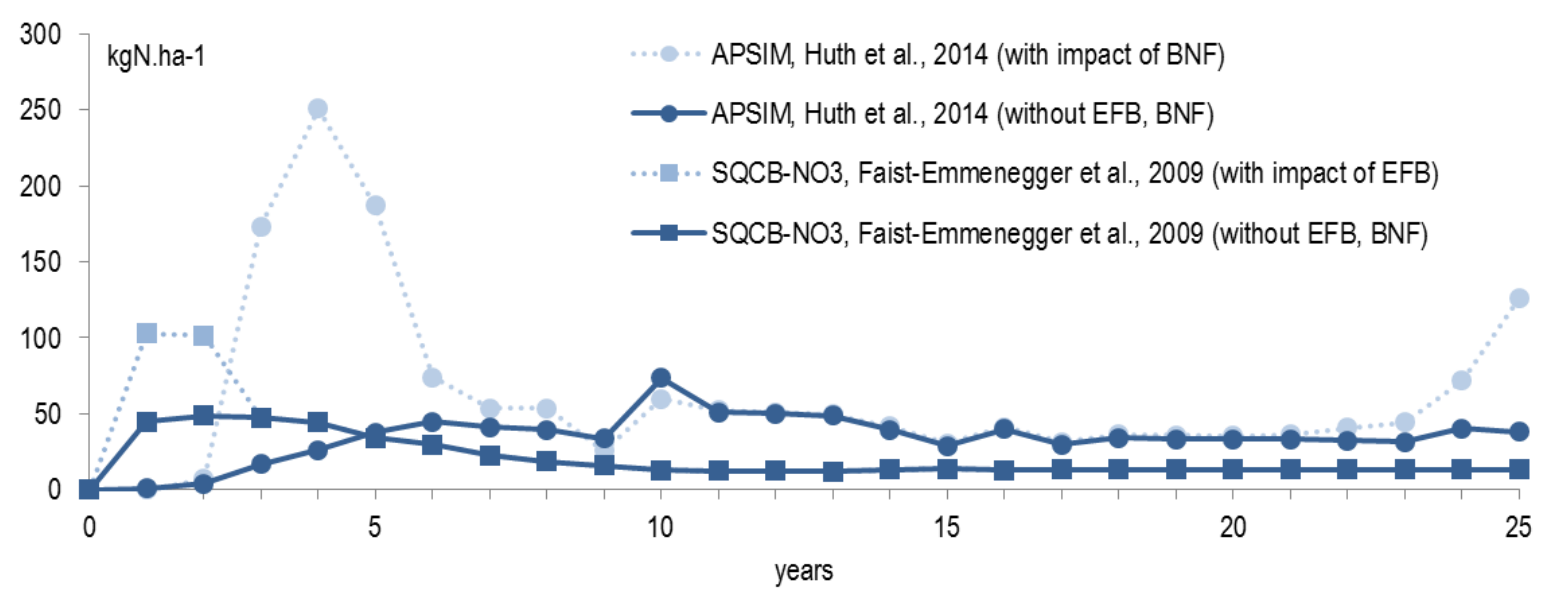

Figure SM1. Influences of EFB and BNF on the temporal patterns of losses through leaching and runoff. The timing of the peak of losses depended on models, and its magnitude depended on which $\mathrm{N}$ inputs were accounted for. Two examples are represented: the influence of BNF in APSIM, and the influence of EFB in SQCB-NO3. BNF: biological N fixation; EFB: empty fruit bunches, i.e. organic fertiliser.

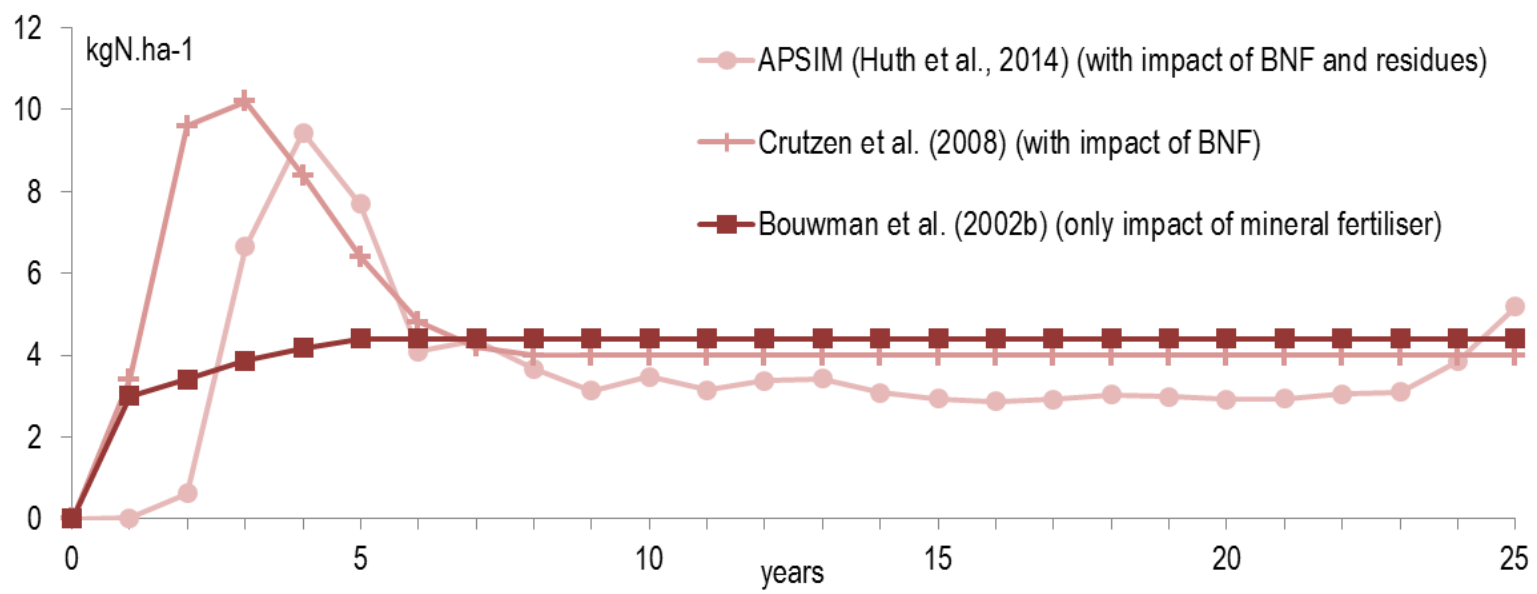

Figure SM2. Influences of previous palm residues, EFB and BNF on the temporal patterns of losses through $\mathbf{N}_{2} \mathrm{O}$ emissions. The sub-models that included mineral fertiliser inputs only did not show any peak of emissions over the crop cycle, e.g. in Bouwman 2002b, whereas the ones taking into account at least one other $\mathrm{N}$ input, such as palm residues or biological $\mathrm{N}$ fixation, showed a peak during the immature period. Three examples are represented: Bouwman 2002b (regression model, influence of mineral fertiliser), Crutzen 2008 (linear regression model, influence of mineral fertiliser and BNF), and APSIM (mechanistic model, with influence of BNF, and previous palm residues). BNF: biological N fixation. 


\section{References}

Agamuthu, P., Broughton, W.J., 1985. Nutrient cycling within the developing oil palm-legume ecosystem. Agric. Ecosyst. Environ. 13, 111-123. doi:10.1016/0167-8809(85)90054-4

Agrammon Group, 2009. Technische Parameter Modell Agrammon. Schweizerische Hochschule für Landwirtschaft SHL.

Banabas, M., 2007. Study of nitrogen loss pathways in oil palm (Elaeis guineensis Jacq.) growing agroecosystems on volcanic ash soils in Papua New Guinea: a thesis presented in partial fulfilment of the requirements for the degree of Doctor of Philosophy in Soil Science at Massey University, Palmerston North, New Zealand.

Bouwman, A.F., Boumans, L.J.M., Batjes, N.H., 2002. Modeling global annual $\mathrm{N}_{2} \mathrm{O}$ and NO emissions from fertilized fields: $\mathrm{N}_{2}$ O AND NO EMISSIONS FROM FERTILIZERS. Glob. Biogeochem. Cycles 16, 28-1-28-9. doi:10.1029/2001GB001812

Broughton, W.J., Earp, D.A., Newall, W., 1977. Effect of various covers on the performance of Elaeis guineensis (Jacq.) on different soils. Int. Dev. Oil Palm 501-525.

Carcasses, R., 2004. Adaptation d'un indicateur agro-environnemental de pollution azotée à la culture du palmier à huile à Sumatra (Mémoire de fin d’études). DAA-ENSA Montpellier-France.

Chew, T.A., Isa, A.B., bin Mohayidin, M.G., 1999. Sago (Metroxylon sagu Rottboll), the forgotten palm. J. Sustain. Agric. 14, 5-17. doi:10.1300/J064v14n04_03

Choo, Y.M., Muhamad, H., Hashim, Z., Subramaniam, V., Puah, C.W., Tan, Y., 2011. Determination of GHG contributions by subsystems in the oil palm supply chain using the LCA approach. Int. J. Life Cycle Assess. 16, 669-681. doi:10.1007/s11367-011-0303-9

Corley, R.H.V., Tinker, P.B.H., 2003. The oil palm. John Wiley \& Sons.

Crutzen, P.J., Mosier, A.R., Smith, K.A., Winiwarter, W., 2008. N2O release from agro-biofuel production negates global warming reduction by replacing fossil fuels. Atmos Chem Phys 8, 389-395. doi:10.5194/acp-8-389-2008

Dufrêne, E., 1989. Photosynthèse, consommation en eau et modélisation de la production chez le palmier à huile. These Dr. En Sci. Univ. Paris Sud Orsay 117-119.

European Environment Agency, 2013. EMEP / technical guidance to prepare national emission inventories. Publications Office, Luxembourg.

FAO, 2004. Fertilizer use by crop in Malaysia. Food and Agriculture Organization of the United Nations (FAO), Rome.

FAO, 2001. GLOBAL ECOLOGICAL ZONING FOR THE GLOBAL FOREST RESOURCES ASSESSMENT 2000. Food and Agriculture Organizat ion of the United Nations, Forestry Department, Rome.

Foster, H., 2003. Assessment of oil palm fertiliser requirements, in: T. H. Fairhurst and R. Hardter (Eds.), Oil Palm - Management for Large and Sustainable Yields. Potash and Phosphate Institute, pp. 231-257.

Foster, H.L., Parabowo, N.E., 2003. Efficient Use of Fertilisers in Oil Palm for Increased Productivity in North Sumatra, in: Proceedings of the PIPOC 2003 International Palm Oil Congress (Agriculture). Malaysian Palm Oil Board: Kuala Lumpur, Malaysia, Putrajaya Marriott Hotel, Putrajaya, Malaysia.

Giller, K.E., Fairhurst, T., 2003. Legume cover plants, in: Oil Palm: Management for Large and Sustainable Yields. by TH Fairhurst and R. Härdter, pp. 151-161.

Goh, K.-J., Härdter, R., Fairhurst, T., 2003. Fertilizing for maximum return, in: Fairhust, T. and Hardter, R., Oil Palm Management for Large and Sustainable Yields. PPI, PPIC and IPI. Potash \& Phosphate Institute., pp. 279-306.

Hansen, S., 2005. Feasibility Study of Performing an Life Cycle Assessment on Crude Palm Oil Production in Malaysia (9 pp). Int. J. Life Cycle Assess. 12, 50-58. doi:10.1065/lca2005.08.226

Henson, I.E., 2004. Modelling carbon sequestration and emissions related to oil palm cultivation and associated land use change in Malaysia. MPOB Technol.

Henson, I.E., 1999. Comparative ecophysiology of oil palm and tropical rainforest, in: Oil Palm and the Environment - a Malaysian Perspective (Ed. by Gurmit Singh et Al.). Oil Palm Growers' Council, Kuala Lumpur, Malay, pp. 9-39.

Henson, I.E., Chai, S.H., 1997. Analysis of oil palm productivity. II. Biomass, distribution, productivity and turnover of the root system. Elaeis 9, 78-92.

IPCC, 2006. N2O emissions from managed soils 2006 IPCC Guidelines for national greenhouse gas inventories., in: Guidelines IPCC 2006.

Jourdan, C., Rey, H., 1997. Architecture and development of the oil-palm (Elaeis guineensis Jacq.) root system. Plant Soil 189, 33-48.

Jourdan, C., Thongo M’Bou, A., Nodichao, L., Noel, C., Maryulius, M., Saint-André, L., Roupsard, O., Nouvellon, Y., Joffre, R., Epron, D., Hamel, O., Rouzière, A., 2003. Fine root dynamics and turnover within tropical perennial plantations. 
Khalid, H., Zin, Z.Z., Anderson, J.M., 1999a. Quantification of oil palm biomass and nutrient value in a mature plantation. I. Above-ground biomass. J. Oil Palm Res. 11, 23-32.

Khalid, H., Zin, Z.Z., Anderson, J.M., 1999b. Quantification of oil palm biomass and nutrient value in a mature plantation. II. Below-ground biomass. J. Oil Palm Res. 11, 63-71.

Khasanah, N., van Noordwijk, M., Ningsih, H., Rahayu, S., 2015. Carbon neutral? No change in mineral soil carbon stock under oil palm plantations derived from forest or non-forest in Indonesia. Agric. Ecosyst. Environ. 211, 195-206. doi:10.1016/j.agee.2015.06.009

Lamade, E., Djegui, N., Leterme, P., 1996. Estimation of carbon allocation to the roots from soil respiration measurements of oil palm. Plant Soil 181, 329-339. doi:10.1007/BF00012067

Lehmann, J., 2003. Subsoil root activity in tree-based cropping systems, in: Roots: The Dynamic Interface between Plants and the Earth. Springer, pp. 319-331.

Nelson, P.N., Banabas, M., Scotter, D.R., Webb, M.J., 2006. Using Soil Water Depletion to Measure Spatial Distribution of Root Activity in Oil Palm (Elaeis guineensis Jacq.) Plantations. Plant Soil 286, 109-121. doi:10.1007/s11104-006-9030-6

Nemecek, 2012. Updated Ecoinvent v3.

Nemecek, T., Schnetzer, J., Reinhard, J., 2014. Updated and harmonised greenhouse gas emissions for crop inventories. Int. J. Life Cycle Assess. 1-18. doi:10.1007/s11367-014-0712-7

Ng, H.C.P., Chew, P.S., Goh, K.J., Kee, K.K., 1999. Nutrient requirements and sustainability in mature oil palms-an assessment. Planter 75, 331-345.

Ng, S.K., 1977. Review of oil palm nutrition and manuring. Scope for greater economy in fertilizer usage. Oleagineux 32, 197-209.

Ng, S.K., Thamboo, S., 1967. Nutrient contents of oil palms in Malaysa. I. Nutrients required for reproduction: fruit bunch and male inflorescences. Malay Agric J 46, 3-45.

Ng, S.K., Thamboo, S., de Souza, P., 1968. Nutrient contents of oil palms in Malaysa. II. Nutrients in vegetative tissues. Malay Agric J 46, 332-391.

Ng, S.K., von Uexküll, H., Härdter, R., 2003. Botanical aspects of the oil palm relevant to crop management. Oil Palm Manag. Large Sustain. Yields”T Fairhurst R Härdter Eds 13-26.

Paramananthan, S., 2015. Soil properties and their influence on oil palm management and yield, in: ACIAR PROCEEDINGS 144. Presented at the Sustainable Management of Soil in Oil Palm Plantings, Australian Government, 7-8 November 2013, Medan, Indonesia, pp. 10-14.

Pushparajah, E., 1981. Nitrogen cycle in rubber (Hevea) cultivation., in: Nitrogen Cycling in South-East Asian Wet Monsoonal Ecosystems. Proceedings of a Regional Workshop Arranged by the SCOPE/UNEP International Nitrogen Unit of the Royal Swedish Academy of Sciences and the Chiang Mai Univ., Thailand, 5-10 Nov 1979. Australian Academy of Science, pp. 101-108.

Pushparajah, E., Chew, P.S., 1998. Integrated nutrient management for sustaining high yield of plantation tree crops in Tropical Asia, in: Malaysian Soil Science Conference in.

Redshaw, M., 2003. Utilization of field residues and mill by-products. Oil Palm Manag. Large Sustain. Yields Singap. PPI PPIC 307-320.

Roy, 2005. Bilan nutritif des sols / FAO [WWW Document]. URL ftp://ftp.fao.org/agl/agll/docs/fpnb14_f.pdf (accessed 2.13.15)

Ruiz, E., López, D.L.M., 2014. Revisión de literatura sobre beneficios asociados al uso de coberturas leguminosas en palma de aceite y otros cultivos permanentes. Rev. Palmas 35, 53-64.

Schmidt, J.H., 2007. Life assessment of rapeseed oil and palm oil. Ph. D. thesis, Part 3: Life cycle inventory of rapeseed oil.

Schroth, G., Rodrigues, M. r. l., D’Angelo, S. a., 2000. Spatial patterns of nitrogen mineralization, fertilizer distribution and roots explain nitrate leaching from mature Amazonian oil palm plantation. Soil Use Manag. 16, 222-229. doi:10.1111/j.1475-2743.2000.tb00197.x

Shcherbak, I., Millar, N., Robertson, G.P., 2014. Global metaanalysis of the nonlinear response of soil nitrous oxide (N2O) emissions to fertilizer nitrogen. Proc. Natl. Acad. Sci. 111, 9199-9204. doi:10.1073/pnas.1322434111

Sommer, R., Denich, M., Vlek, P.L., 2000. Carbon storage and root penetration in deep soils under small-farmer land-use systems in the Eastern Amazon region, Brazil. Plant Soil 219, 231-241.

Stehfest, E., Bouwman, L., 2006. N2O and NO emission from agricultural fields and soils under natural vegetation: summarizing available measurement data and modeling of global annual emissions. Nutr. Cycl. Agroecosystems 74, 207-228. doi:10.1007/s10705-006-9000-7

Tan, K.S., 1977. Efficient fertiliser usage for oil palm on inland soils, in: Earp, D.A. and Newall, S. (eds.) International Developments in Oil Palm. Malaysian International Agricultural Oil Palm Conference, Kuala Lumpur, pp. 262- 288.

Tan, K.S., 1976. Development, nutrient contents and productivity in oil palm on inland sils of West Malaysia. MSc Univ. Singap. 
Trebs, I., Lara, L.S., Zeri, L.M., Gatti, L.V., Artaxo, P., Dlugi, R., Slanina, J., Andreae, M.O., Meixner, F.X., 2006. Dry and wet deposition of atmospheric inorganic nitrogen in a tropical environment (Rondônia, Brazil). Atmos Chem Phys 6, 447-469.

Turner, P.D., Gillbanks, R.A., 2003. Oil palm cultivation and management. Incorporated Society of Planters.

United Plantations Berhad, 2006. Annual Report 2005. United Plantations Berhad, Teluk Intan, Malaysia.

USDA, 1999. Soil Taxonomy. A Basic System of Soil Classification for Making and Interpreting Soil Surveys., Agriculture Handbook. United States Department of Agriculture Natural Resources Conservation Service.

Wicke, B., Dornburg, V., Junginger, M., Faaij, A., 2008. Different palm oil production systems for energy purposes and their greenhouse gas implications. Biomass Bioenergy 32, 1322-1337.

Xaviar, A., 2000. Fertiliser requirement of oil palms for high yields: some thoughts, in: Managing Oil Palm for High Yields: Agronomic Principles. Goh K.J., Kuala Lumpur, pp. 74-97. 